\title{
Assessment of sulfur concrete properties for use in civil engineering
}

\author{
Michat Lewandowski ${ }^{1, *}$, and Renata Kotynia ${ }^{1}$ \\ ${ }^{1}$ Lodz University of Technology, Department of Concrete Structures, al. Politechniki 6, 90-942 Lodz, \\ Poland
}

\begin{abstract}
Sulfur concrete is a material that was introduced to the civil engineering industry as a substitute of a typical concrete in which cement is a binder. Sulfur concrete properties are provided by a sulfur polymer produced in the process of synthesis of the ordinary sulfur with modifiers that prevent a process of crystallization of sulfur what results in stabilizing sulfur polymer structure. The purpose of this investigation was to evaluate characteristics of sulfur concrete, which was designed with combustion products. It was established that mechanical parameters of sulfur concrete should correspond with properties of a cement concrete used in production processes of prefabricated elements of road and construction industry. Accurateness of parameters of a designed mixture was confirmed and rated by a series of tests of hardened concrete - physical, mechanical (compression strength), durability in harsh environment. The test results confirmed low water absorption, high resistance to wear abrasion, high freeze-thaw scaling resistance (surface weathering) in a salty environment and high compressive and tensile strength of individual compositions. However, due to the internal structural damage, the freeze-thaw-attack cube tests did not prove the freeze-thaw resistance of the sulfur concrete specimens. The reason was low freeze-thaw-attack resistance of sulfur binders.
\end{abstract}

\section{Introduction}

Sulfur, used in this research, is the so-called "recycled sulfur" due to fact that it is obtained in action of purifying fuel - natural gas, oil, coal, however it is characterized with high purity: $99,95 \%$ content of elementary sulfur. Although its satisfactory quality, most of the produced sulfur is placed at stockpiles.

Natural result of sulfur resources growth is the increase of research on a new application of this product. Replacement of a cement with a sulfur polymer as a binder in concrete compounds, is one of the analyzed directions of solving a problem of a sulfur waste. The first attempts of utilizing sulfur as a binder for concrete compounds date back to the 1920s. The first results have shown that the new material showed a tendency to lose its mechanical properties in time. It was probably caused by disintegration of internal sulfur polymer bonds. Additionally, first sulfur concrete samples were susceptible to freeze-thaw cycles

\footnotetext{
*Corresponding author: michal.lewandowski@p.lodz.pl
} 
and humid or water environment [1]. In order to solve this problem, several modifiers of standard properties of sulfur binder were prospected.

Modifiers, such as dicyclopentadien, styrene, turpentine, furfural, are substances that added to the liquid sulfur polymer, change its physio-chemical properties by impeding process of crystallization of sulfur, it results in stabilization of polymer structure with physical parameters irrespective of a passing time. The advantage of using the modified sulfur polymer as a binder in manufacturing sulfur concrete is the ability of fast compressive strength gaining. It is estimated that full compressive strength of produced elements is reached after 24 hours from its forming. This is a result of the incubating process, directly affected by solidification of the product.

Another benefit of sulfur concrete products is the possibility of utilization wastes, whose amount at stockpiles is still increasing. According to GUS [2] (central statistical office) data from 2014, in Poland it was produced 131,3 million tons of industrial waste materials from which only $27,6 \%$ was recycled. The total mass of wastes kept at stockpiles (data from the end of 2014) has reached 1683,5 million tons. Materials that are most frequently stored at stockpiles nearby power plants and electrical power and heating stations are slags and fly ashes - by-products of coal combustion.

A beneficial feature of a sulfur concrete is a possibility of applying all kind of wastes regardless to their quality - those types of additives do not come into reaction with a binder and might be used as fillers. Using wastes, which without additional refinement do not comply with requirements of additives used in civil engineering and despite this might be used as fillers of sulfur concrete products of small architecture without any risk, resulting in economic and ecological benefits.

Based on literature, sulfur concrete is characterized by high durability in harsh environments such as salt or acidic solutions, is unresponsive to biodegradation, radiation activity and is proof to freeze - thaw cycles, is material hardly absorbing liquids, has high compression strength, is easily recyclable [3-7]. Due to all of mentioned advantages of sulfur concrete, there is a wide range of potential applications of this product.

\section{Component materials and production methods}

\subsection{Sulfur polymer}

Sulfur polymers are materials produced from natural sulfur modified by chemical substances that are added at strictly defined conditions and proportions. The following modifiers: dicyclopentadiene (DCPD), styrene, turpentine and furfural are added to the liquefied sulfur to transform properties of this material by inhibiting its crystallization - that stabilizes the structure enabling preservation of consistent physical properties irrespectively the time. All of them are high-boiling liquids or low setting solids imparting the binder with plasticity. They undergo co-polymerization with particles of a sulfur in a temperature of $140^{\circ} \mathrm{C}$, creating linear (styrene) or cross-linked (DCPD) structures - depending on a type of modifier [8]. The influence of produced sulfur polymers on people's health was not tested yet, but tests conducted by National Institute of Hygiene of Poland (No. HK/W/1008/01/2009) on other sulfur mortar have confirmed safety of use of tested sulfur polymer.

\subsection{Aggregate}

An aggregate used in the project was selected with a special emphasis on achieving satisfactory mechanical parameters of the product. The secondary criterion of an aggregate 
selection was the economical aspect. The following types of an aggregate commonly used in a typical cement concrete were applied in the project: sand, gravel, granite and dolomite.

Additives in the sulfur concrete (fly ash, phosphogypsum) were selected to obtain intended grain curve consistent with ACI 5482 code [1]. Two main aims were considered in additives assortment. A fine-grained dust sealing the aggregate matrix was used as the first one, and cheaper and easily accessible waste materials, stored in huge amounts at stockpiles, were utilized in the second. At the same time it favors competitiveness of the product considering the economic aspect as additives fly ash and phosphogypsum have been used.

\subsection{Production process}

Production process of a sulfur concrete based on melting of an elementary sulfur and simultaneous mixing it with modifiers at the temperature in a range between 130 and $140^{\circ} \mathrm{C}$. Heated up aggregate and other additives are added to a liquidized sulfur polymer binder and mixed all together. Finally, after obtaining homogeneous compound, it is ready to be poured into molds. In the research, cubic and cuboid forms were used. From one batch, usually about 16 cubic and 9 cuboid samples were performed. The details of batch compositions are presented in Table 1.

Table 1. Selected compositions of batches.

\begin{tabular}{|c|c|c|c|c|c|c|c|c|c|}
\hline \multirow[t]{2}{*}{ No. } & \multirow{2}{*}{$\begin{array}{l}\text { Batch } \\
\text { No. }\end{array}$} & \multirow{2}{*}{$\begin{array}{c}\text { Sulfur } \\
\%\end{array}$} & \multicolumn{2}{|c|}{ Modifier } & \multirow{2}{*}{$\begin{array}{l}\text { Sand } \\
\%\end{array}$} & \multicolumn{2}{|c|}{$\begin{array}{l}\text { Coarse aggregate } \\
2-8 \mathrm{~mm}\end{array}$} & \multicolumn{2}{|c|}{ Additive } \\
\hline & & & Type & $\%$ & & Type & $\%$ & Type & $\%$ \\
\hline 1 & 3 & 30 & - & - & 60 & - & - & fly ash & 10,0 \\
\hline 2 & 6 & 22,5 & str & 2,5 & 62,5 & - & - & fly ash & 12,5 \\
\hline 3 & 8 & 22,5 & str & 2,5 & 61,0 & - & - & fly ash & 14,0 \\
\hline 4 & 10 & 22,5 & $\begin{array}{l}\text { str } \\
\text { tur }\end{array}$ & $\begin{array}{l}1,25 \\
1,25\end{array}$ & 62,5 & - & - & fly ash & 12,5 \\
\hline 5 & 12 & 19,0 & dcpd & 1,0 & 20,0 & gravel & 60,0 & - & - \\
\hline 6 & 15 & 19,0 & dcpd & 1,0 & 20,0 & granite & 60,0 & - & - \\
\hline 7 & 16 & 19,0 & dcpd & 1,0 & 20,0 & dolomite & 60,0 & - & - \\
\hline 8 & 20 & 21,1 & dcpd & 1,1 & 15,6 & gravel & 54,4 & fly ash & 7,8 \\
\hline 9 & 22 & 24,5 & dcpd & 1,3 & 6,4 & gravel & 58,7 & $\mathrm{ph}$ & 9,1 \\
\hline 10 & 24 & 24,5 & $\begin{array}{l}\text { dcpd } \\
\text { fur }\end{array}$ & $\begin{array}{l}0,65 \\
0,65\end{array}$ & 13,1 & gravel & 52,0 & fly ash & 9,1 \\
\hline 11 & 25 & 24,5 & $\begin{array}{l}\text { dcpd } \\
\text { fur }\end{array}$ & $\begin{array}{l}0,65 \\
0,65\end{array}$ & 13,1 & gravel & 52,0 & ph & 9,1 \\
\hline 12 & 26 & 21,1 & dcpd & 1,1 & 20,0 & gravel & 57,8 & - & - \\
\hline 13 & 27 & 24,5 & dcpd & 1,3 & 13,1 & gravel & 52,0 & fly ash & 9,1 \\
\hline 14 & 28 & 24,5 & dcdp & 1,3 & 13,1 & gravel & 52,0 & $\mathrm{ph}$ & 9,1 \\
\hline 15 & 30 & 21,1 & dcpd & 1,1 & 20,0 & gravel & 57,8 & - & - \\
\hline \multicolumn{10}{|c|}{$\begin{array}{l}\text { Abbreviations: } \\
\text { dcpd-dicyclopentadiene } \\
\text { ph-phosphogypsum } \\
\text { str - styrene } \\
\text { tur - turpentine } \\
\text { fur - furfural }\end{array}$} \\
\hline
\end{tabular}




\subsection{Experimental tests}

The main aim of the batch composition was to produce durable sulfur concrete products, able to withstand environmental conditions, their exposure should be highly durable and immune to weather conditions. The following mechanical and durability tests were carried out:

- Water absorption [9]

- Bulk density [9]

- Compressive strength [10]

- Bending tensile strength [11]

- Determination of ultrasonic pulse velocity [12]

- Freeze-thaw resistance [9]

- Freeze-thaw resistance in salty environment - scaling [13]

- Abrasion resistance [13]

All of experimental tests were carried out according to the European or National Standards listed in references.

Additionally, after performing series of freeze - thaw cycles to sulfur concrete specimens, it was decided to test freeze - thaw resistance of sulfur polymer itself. Tests were conducted according to the Polish Standard PKN-CEN/TS 12390-9:2007 [14].

\section{Test results}

Cuboid polymer specimens of sulfur polymer $(40 \times 40 \times 160 \mathrm{~mm})$ were subjected to the freeze - thaw cycle test in a temperature ranged between $-20^{\circ} \mathrm{C}$ and $+20^{\circ} \mathrm{C}$ within one cycle. All specimens, irrespectively of the modifier, cracked in a short time after freeze - thaw cycles have begun (Fig.1). First cracks have appeared on a surface of polymer specimens within first 72 hours, full cracks (when a specimen breaks) were observed after 7 days from beginning of the tests.

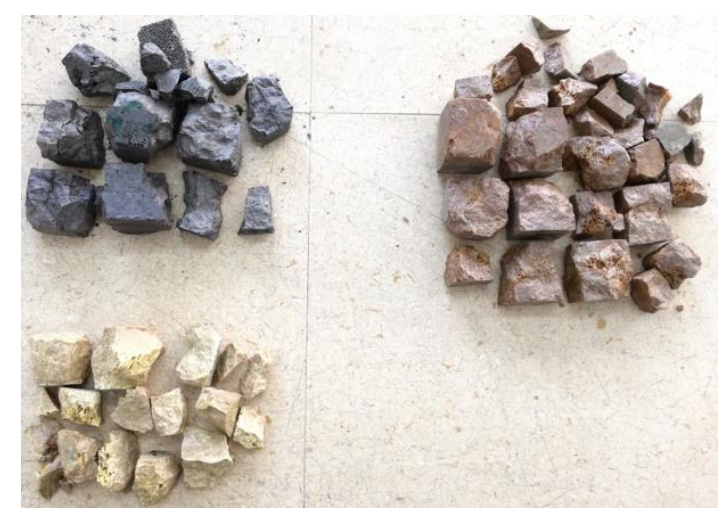

Fig. 1. Cuboid samples of sulfur polymers after 75 freeze - thaw cycles.

The polymeric binders were not affected by additives such as flying ash and phosphogypsum. Application of additives in dust form and aggregate of a good quality guarantees obtaining product of low water absorption and high compressive strength. Application of coarse aggregate with $2-8 \mathrm{~mm}$ graining in the mixture resulted with a significant improvement of strength parameters of sulfur concrete (Table 2, Fig. 2). 
Table 2. Mechanical parameters of selected sulfur concrete batches.

\begin{tabular}{|c|c|c|c|c|c|c|c|c|}
\hline \multirow{2}{*}{ No. } & \multirow{2}{*}{$\begin{array}{c}\text { Batch } \\
\text { No. }\end{array}$} & Density & $\begin{array}{c}\text { Water } \\
\text { absorption }\end{array}$ & \multicolumn{2}{|c|}{$\begin{array}{c}\text { Compressive } \\
\text { strength }[\mathrm{MPa}]\end{array}$} & \multicolumn{2}{|c|}{$\begin{array}{c}\text { Bending strength } \\
{[\mathrm{MPa}]}\end{array}$} & $\begin{array}{c}\text { Ultrasonic } \\
\text { wave } \\
\text { velocity } \\
{[\mathrm{km} / \mathrm{s}]}\end{array}$ \\
\cline { 3 - 8 } & & {$\left[\mathrm{kg} / \mathrm{m}^{3}\right]$} & {$[\%]$} & Early & Late & Early & Late & - \\
\hline 1 & 3 & 2285 & - & 41,0 & 41,0 & 4,3 & - & 3,44 \\
\hline 2 & 6 & 2160 & 0,23 & 14,5 & 18,0 & 4,2 & 4,2 & 3,15 \\
\hline 3 & 8 & 2053 & 0,37 & 12,1 & 14,2 & 4,1 & 4,1 & 3,23 \\
\hline 4 & 10 & 2029 & 0,36 & 11,2 & 14,1 & 3,4 & 3,8 & 3,91 \\
\hline 5 & 12 & 2351 & 0,35 & 57,3 & 56,1 & 8,7 & 7,7 & 3,82 \\
\hline 6 & 15 & 2296 & 0,31 & 65,6 & 53,4 & 5,2 & - & 4,15 \\
\hline 7 & 16 & 2387 & 0,47 & 57,0 & 51,7 & 7,3 & - & 4,07 \\
\hline 8 & 20 & 2235 & 0,07 & 50,6 & 68,7 & 13,3 & 10,4 & 3,97 \\
\hline 9 & 22 & 2300 & 0,10 & 39,7 & 45,8 & 7,4 & 2,3 & 3,94 \\
\hline 10 & 24 & 2241 & 0,06 & 38,4 & 41,9 & 4,9 & 5,3 & 3,79 \\
\hline 11 & 25 & 2256 & 0,04 & 49,6 & 50,5 & 4,5 & 3,7 & 3,89 \\
\hline 12 & 26 & 2420 & 0,25 & 54,5 & 54,6 & 5,5 & 5,8 & 3,82 \\
\hline 13 & 27 & 2341 & 0,04 & 58,7 & 58,2 & 10,1 & 10,0 & 3,91 \\
\hline 14 & 28 & 2390 & 0,04 & 61,8 & 51,3 & 8,0 & 5,7 & 3,76 \\
\hline 15 & 30 & 2300 & 0,13 & 55,4 & 44,9 & 7,0 & 5,5 & \\
\hline
\end{tabular}

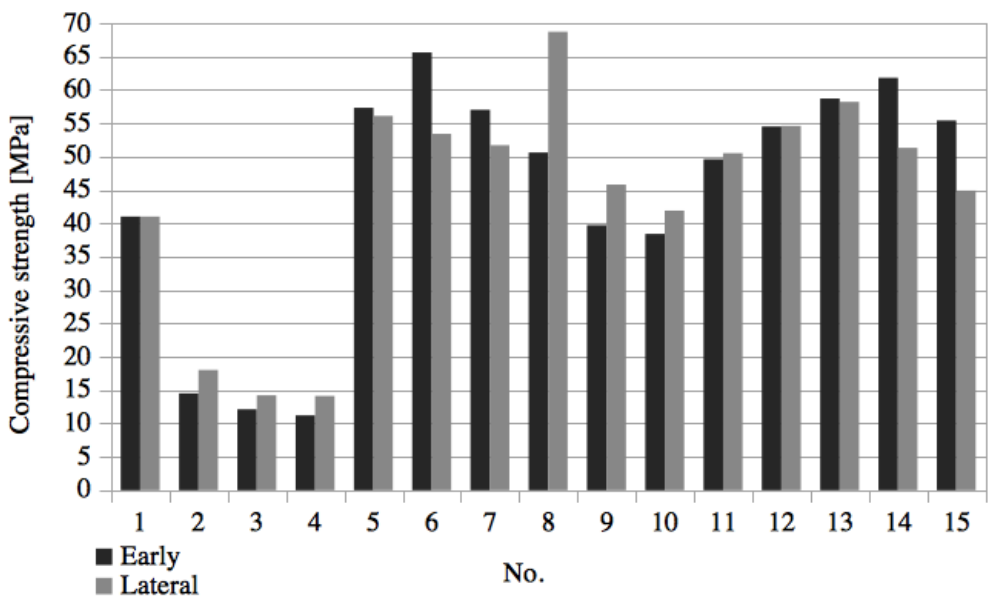

Fig. 2. Comparison of early and late strength of sulfur concrete samples.

Modification of sulfur polymer with styrene (STR) significantly decreased strength of the sulfurous mortar from 41,0 MPa to approximately 14,5 MPa. Natural aggregate (gravel, granite, dolomite) did not influence the compound strength. The curing time of samples did not affect the compressive or bending tensile strength. Early strength (1-4 days of age) and late strength after 28 days were similar (Fig. 2). The differences between the investigated parameters were caused by heterogeneity of the samples. The main reason of the results dispersion was varied conditions of samples casting. The time of casting is strictly limited, so the temperature changes significantly affected the final strength of sulfur concrete specimens. Additionally, differences in bending tensile strength observed on specimens tested in early and late stage of incubation might be connected with excessive maximum aggregate dimension contained in sulfur concrete $(8 \mathrm{~mm})$ for that kind of form $(40 \times 40 \times 160$ $\mathrm{mm}$ ), which is designed to test mortar parameters (maximum aggregate dimension of $4 \mathrm{~mm})$. 
The freeze-thaw resistance of sulfur concrete was conducted using volumetric and surface method. In the first one the strength loss limit is $20 \%$ of reference specimen strength and cracks on the surface of samples subjected to a specific number of freezingthawing cycles are not allowed. According to the Polish standard [14], concrete members used in the road infrastructure require the freeze-thaw resistance of F150, which corresponds to 150 freeze-thaw cycles. Several test specimens did not meet those requirements (Table 3 ).

Table 3. Durability test results of selected sulfur concrete batches.

\begin{tabular}{|c|c|c|c|c|c|}
\hline \multirow{2}{*}{ No. } & \multirow{3}{*}{$\begin{array}{c}\text { Batch } \\
\text { No. }\end{array}$} & \multicolumn{5}{|c|}{ Freeze-thaw resistance, samples compressive strength } \\
& & Reference & Tested & $\begin{array}{c}\text { Strength } \\
\text { loose }\end{array}$ & $\begin{array}{c}\text { Number of } \\
\text { cycles }\end{array}$ \\
\cline { 3 - 6 } & & - & - & - & - \\
\hline 1 & 3 & 16,6 & 12,0 & $28 \%$ & 200 \\
\hline 2 & 6 & 11,4 & 10,2 & $11 \%$ & 200 \\
\hline 3 & 8 & 12,5 & 9,1 & $27 \%$ & 200 \\
\hline 4 & 10 & 61,9 & 26,2 & $58 \%$ & 200 \\
\hline 5 & 12 & 56,1 & 36,3 & $35 \%$ & 200 \\
\hline 6 & 15 & 51,2 & $13 \%$ & 200 \\
\hline 7 & 16 & 35,8 & 31,2 & 100 \\
\hline 8 & 20 & 65,5 & 46,8 & $29 \%$ & 200 \\
\hline 9 & 22 & 46,9 & 14,7 & $69 \%$ & 200 \\
\hline 10 & 24 & 42,7 & 29,3 & $31 \%$ & 100 \\
\hline 11 & 25 & 50,4 & 7,7 & $85 \%$ & 150 \\
\hline 12 & 26 & 54,2 & 8,1 & $85 \%$ & 150 \\
\hline 13 & 27 & 55,4 & 31,5 & $43 \%$ & 150 \\
\hline 14 & 28 & 58,1 & 42,6 & $27 \%$ & 150 \\
\hline 15 & 30 & 59,1 & 43,6 & $26 \%$ & \\
\hline
\end{tabular}

At the same time, frost resistance evaluated with the second method, by measuring the surface exfoliation of samples in water solution of de-icing salt $(\mathrm{NaCl})$, proved sulfur concrete very resistant (Table 4). The summary amount of the exfoliated material after 28 freeze-thaw cycles expressed in $\mathrm{kg} / \mathrm{m}^{2}$ was exiguous, and after 56 cycles did not exceed 0,3 $\mathrm{kg} / \mathrm{m}^{2}$.

The obtained abrasion test results affirmed that selected compositions of sulfur concrete are highly resistant to abrasion. The tested samples qualifies for the highest, $4^{\text {th }}$ class of abrasion resistance according to [13] (Table 5).

Table 4. Durability tests results - freeze-thaw resistance in 3\% salt solution (scaling).

\begin{tabular}{|c|c|c|c|c|}
\hline $\begin{array}{c}\text { Specimen } \\
\text { No. }\end{array}$ & $\begin{array}{c}\text { Mass of scaled } \\
\text { material after 28 } \\
\text { cycles (g) }\end{array}$ & $\begin{array}{c}\text { Mass of scaled } \\
\text { material after 56 } \\
\text { cycles }(\mathrm{g})\end{array}$ & $\begin{array}{c}\text { Mass of scaled } \\
\text { material after 28 } \\
\text { cycles }\left(\mathrm{kg} / \mathrm{m}^{2}\right)\end{array}$ & $\begin{array}{c}\text { Mass of scaled } \\
\text { material after 56 } \\
\text { cycles }\left(\mathrm{kg} / \mathrm{m}^{2}\right)\end{array}$ \\
\hline 1A & 1,50 & 2,51 & 0,16 & 0,26 \\
\hline 2A & 1,05 & 1,78 & 0,11 & 0,19 \\
\hline 3A & 0,21 & 0,64 & 0,02 & 0,07 \\
\hline 4A & 0,24 & 1,36 & 0,03 & 0,14 \\
\hline 5B & 0,03 & 0,11 & 0,00 & 0,01 \\
\hline 6B & 0,07 & 0,36 & 0,01 & 0,04 \\
\hline 7B & 0,01 & 0,10 & 0,00 & 0,01 \\
\hline 8B & 0,01 & 0,13 & 0,00 & 0,01 \\
\hline
\end{tabular}


Table 5. Durability test results of selected sulfur concrete batches.

\begin{tabular}{|c|c|c|c|}
\hline \multirow{2}{*}{$\begin{array}{c}\text { Specimen } \\
\text { No. }\end{array}$} & mean value & $\begin{array}{c}\text { width of groove }(\mathrm{mm}) \\
\text { results in correlation to } \\
\text { calibration sample }\end{array}$ & \multirow{2}{*}{$\begin{array}{c}\text { Class } 4 \\
\leq 20 \mathrm{~mm}\end{array}$} \\
\cline { 2 - 3 } & 15,1 & 20,0 & \\
\hline 2 & 14,4 & 19,0 & \\
\hline 3 & 15,0 & 19,5 & \\
\hline 4 &
\end{tabular}

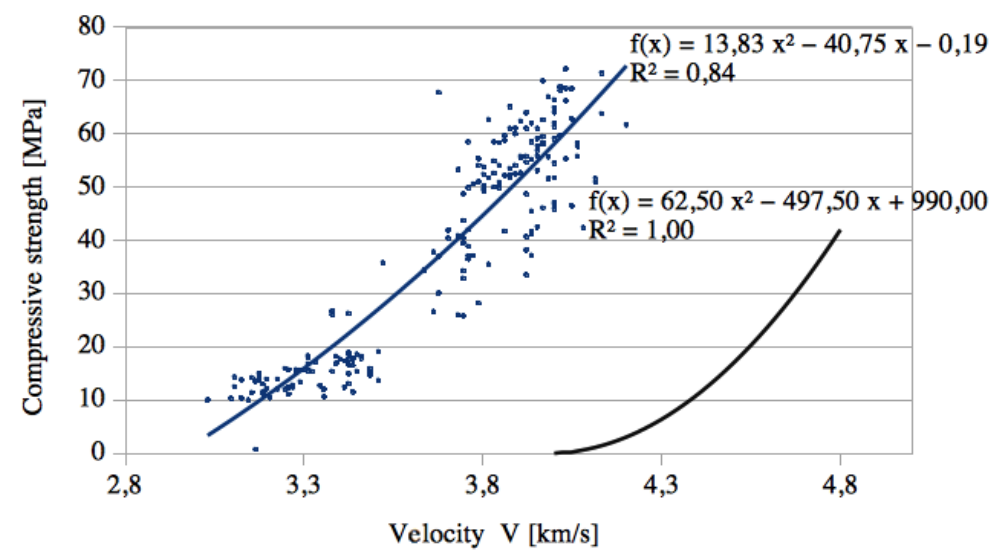

Fig. 3. Correlation curve of Compressive Strength - Velocity for sulfur concrete in comparison to standard curve for cement concrete according to PN-EN 13791.

In order to determine the compressive strength of sulfur concrete an ultrasonic pulse velocity method was used as well. The speed of wave for particular batches were repeatable and fall into between 24,1 and $31,0 \mu \mathrm{s}$, with an average speed value of $26,6 \mu \mathrm{s}$, which corresponded to a wave velocity of $3,76 \mathrm{~km} / \mathrm{s}$. The correlation between the velocity of an ultrasonic pulse in concrete and its compressive strength was estimated basing on the hypothetical curves or a reference tests. Acoustic parameters significantly depend on the tested material. For a typical, well condensed cement concrete with a density between 1800 and $2500 \mathrm{~kg} / \mathrm{m}^{3}$, the velocity varies between 3,0 to $4,8 \mathrm{~km} / \mathrm{s}$. The correlation between compressive strength and wave velocity for sulfur concrete in reference to the normalized curve for cement concrete is presented in Fig 3.

\section{Discussion}

The presented test results of sulfur concrete confirm low water absorption and high resistance to grating in dry conditions. The composite proved high freeze-thaw resistance in salty environment and can be recommended for production of small-sized prefabricated elements. Furthermore, the compressive and tensile strength of individual compositions allowed to design products of a high strength class. However, the sulfur concrete did not prove freeze-thaw resistance with cyclical freezing in the air and the thawing in a water. The probable reason of the vulnerability was the sulfur binder. Regarding this, the products made of the sulfur concrete cannot be exposed to severe conditions in Polish climate (XF class of environment exposition), as their durability does not meet the requirements of the Standards.

The research results clearly indicate that the material can be applied in the construction industry mostly for indoor and underwater or underground applications, below the freezing zone (for example underground cesspits). 
The additional restraint are sulfur's flammable properties, which are usually omitted, and relatively low melting temperature - around $130^{\circ} \mathrm{C}$.

Apart from further freeze-thaw resistance development, the evaluation of abrasion in water conditions is highly recommended due to possible application in underwater environment and all types of piping. Production of larger, reinforced sulfur concrete's members or even structures also requires further testing, but the starting point is the application of reinforcement that is immune to or properly protected from a corrosion. The composite bars seem to be a natural solution as the sulfur concrete occurs to be highly aggressive environment for conventional steel reinforcement.

In conclusion, despite the limitations of the obtained sulfur concrete composition, its potential applications are numerous and also economically justified.

The authors acknowledge financial support from the National Center for Research and Development and National Fund for Environmental Protection and Water Management for the applied research project GEKON No1/O5/213122/26/2015.

\section{References}

1. ACI Committee 548, ACI 548.2R-93 (Reapproved 1998) - Guide for Mixing and Placing Sulfur Concrete in Construction (1998)

2. Central Statistical Office - Statistical Information and Elaborations (2015)

3. M. Abdel-Mohsen, M. El Gama, Cement and Concrete Composites, 31, 186-194, (2009)

4. M.M. Vlahovic, Martinovic, Construction and Building Materials, 25, 3926-3934, (2011)

5. S. Myoungsu, K. Kyuhun, Construction and Building Materials, 69, 167-176 (2014)

6. M. M. Vlahovic, M. M. Savic, Materials and Design, 34, 346-354 (2011)

7. M. Abdel-Mohsen, D. Amr El, Journal of Environmental Geotechnics, 2(2), 95-103 (2014)

8. I. Błasiak, Ł. Łuszczyk, Chemik 41(9), 243 (1988)

9. PN-88 B-06250 - Ordinary Concrete

10. PN-EN 12390-3:2011 - Testing hardened concrete - Part 3: Compressive strength of test specimens

11. PN-EN 196-1:2016-07 - Methods of testing cement - Part 1: Determination of strength

12. PN-EN 12504-4:2005-09 Testing concrete. Determination of ultrasonic pulse velocity

13. PN-EN 1338:2005 - Concrete paving blocks - Requirements and test methods

14. PKN-CEN/TS 12390-9:2007 - Testing hardened concrete - Part 9: Freeze-thaw resistance - Scaling 
and humid or water environment [1]. In order to solve this problem, several modifiers of standard properties of sulfur binder were prospected.

Modifiers, such as dicyclopentadien, styrene, turpentine, furfural, are substances that added to the liquid sulfur polymer, change its physio-chemical properties by impeding process of crystallization of sulfur, it results in stabilization of polymer structure with physical parameters irrespective of a passing time. The advantage of using the modified sulfur polymer as a binder in manufacturing sulfur concrete is the ability of fast compressive strength gaining. It is estimated that full compressive strength of produced elements is reached after 24 hours from its forming. This is a result of the incubating process, directly affected by solidification of the product.

Another benefit of sulfur concrete products is the possibility of utilization wastes, whose amount at stockpiles is still increasing. According to GUS [2] (central statistical office) data from 2014, in Poland it was produced 131,3 million tons of industrial waste materials from which only $27,6 \%$ was recycled. The total mass of wastes kept at stockpiles (data from the end of 2014) has reached 1683,5 million tons. Materials that are most frequently stored at stockpiles nearby power plants and electrical power and heating stations are slags and fly ashes - by-products of coal combustion.

A beneficial feature of a sulfur concrete is a possibility of applying all kind of wastes regardless to their quality - those types of additives do not come into reaction with a binder and might be used as fillers. Using wastes, which without additional refinement do not comply with requirements of additives used in civil engineering and despite this might be used as fillers of sulfur concrete products of small architecture without any risk, resulting in economic and ecological benefits.

Based on literature, sulfur concrete is characterized by high durability in harsh environments such as salt or acidic solutions, is unresponsive to biodegradation, radiation activity and is proof to freeze - thaw cycles, is material hardly absorbing liquids, has high compression strength, is easily recyclable [3-7]. Due to all of mentioned advantages of sulfur concrete, there is a wide range of potential applications of this product.

\section{Component materials and production methods}

\subsection{Sulfur polymer}

Sulfur polymers are materials produced from natural sulfur modified by chemical substances that are added at strictly defined conditions and proportions. The following modifiers: dicyclopentadiene (DCPD), styrene, turpentine and furfural are added to the liquefied sulfur to transform properties of this material by inhibiting its crystallization - that stabilizes the structure enabling preservation of consistent physical properties irrespectively the time. All of them are high-boiling liquids or low setting solids imparting the binder with plasticity. They undergo co-polymerization with particles of a sulfur in a temperature of $140^{\circ} \mathrm{C}$, creating linear (styrene) or cross-linked (DCPD) structures - depending on a type of modifier [8]. The influence of produced sulfur polymers on people's health was not tested yet, but tests conducted by National Institute of Hygiene of Poland (No. HK/W/1008/01/2009) on other sulfur mortar have confirmed safety of use of tested sulfur polymer.

\subsection{Aggregate}

An aggregate used in the project was selected with a special emphasis on achieving satisfactory mechanical parameters of the product. The secondary criterion of an aggregate 
selection was the economical aspect. The following types of an aggregate commonly used in a typical cement concrete were applied in the project: sand, gravel, granite and dolomite.

Additives in the sulfur concrete (fly ash, phosphogypsum) were selected to obtain intended grain curve consistent with ACI 5482 code [1]. Two main aims were considered in additives assortment. A fine-grained dust sealing the aggregate matrix was used as the first one, and cheaper and easily accessible waste materials, stored in huge amounts at stockpiles, were utilized in the second. At the same time it favors competitiveness of the product considering the economic aspect as additives fly ash and phosphogypsum have been used.

\subsection{Production process}

Production process of a sulfur concrete based on melting of an elementary sulfur and simultaneous mixing it with modifiers at the temperature in a range between 130 and $140^{\circ} \mathrm{C}$. Heated up aggregate and other additives are added to a liquidized sulfur polymer binder and mixed all together. Finally, after obtaining homogeneous compound, it is ready to be poured into molds. In the research, cubic and cuboid forms were used. From one batch, usually about 16 cubic and 9 cuboid samples were performed. The details of batch compositions are presented in Table 1.

Table 1. Selected compositions of batches.

\begin{tabular}{|c|c|c|c|c|c|c|c|c|c|}
\hline \multirow[t]{2}{*}{ No. } & \multirow{2}{*}{$\begin{array}{l}\text { Batch } \\
\text { No. }\end{array}$} & \multirow{2}{*}{$\begin{array}{c}\text { Sulfur } \\
\%\end{array}$} & \multicolumn{2}{|c|}{ Modifier } & \multirow{2}{*}{$\begin{array}{l}\text { Sand } \\
\%\end{array}$} & \multicolumn{2}{|c|}{$\begin{array}{l}\text { Coarse aggregate } \\
2-8 \mathrm{~mm}\end{array}$} & \multicolumn{2}{|c|}{ Additive } \\
\hline & & & Type & $\%$ & & Type & $\%$ & Type & $\%$ \\
\hline 1 & 3 & 30 & - & - & 60 & - & - & fly ash & 10,0 \\
\hline 2 & 6 & 22,5 & str & 2,5 & 62,5 & - & - & fly ash & 12,5 \\
\hline 3 & 8 & 22,5 & str & 2,5 & 61,0 & - & - & fly ash & 14,0 \\
\hline 4 & 10 & 22,5 & $\begin{array}{l}\text { str } \\
\text { tur }\end{array}$ & $\begin{array}{l}1,25 \\
1,25\end{array}$ & 62,5 & - & - & fly ash & 12,5 \\
\hline 5 & 12 & 19,0 & dcpd & 1,0 & 20,0 & gravel & 60,0 & - & - \\
\hline 6 & 15 & 19,0 & dcpd & 1,0 & 20,0 & granite & 60,0 & - & - \\
\hline 7 & 16 & 19,0 & dcpd & 1,0 & 20,0 & dolomite & 60,0 & - & - \\
\hline 8 & 20 & 21,1 & dcpd & 1,1 & 15,6 & gravel & 54,4 & fly ash & 7,8 \\
\hline 9 & 22 & 24,5 & dcpd & 1,3 & 6,4 & gravel & 58,7 & $\mathrm{ph}$ & 9,1 \\
\hline 10 & 24 & 24,5 & $\begin{array}{l}\text { dcpd } \\
\text { fur }\end{array}$ & $\begin{array}{l}0,65 \\
0,65\end{array}$ & 13,1 & gravel & 52,0 & fly ash & 9,1 \\
\hline 11 & 25 & 24,5 & $\begin{array}{l}\text { dcpd } \\
\text { fur }\end{array}$ & $\begin{array}{l}0,65 \\
0,65\end{array}$ & 13,1 & gravel & 52,0 & ph & 9,1 \\
\hline 12 & 26 & 21,1 & dcpd & 1,1 & 20,0 & gravel & 57,8 & - & - \\
\hline 13 & 27 & 24,5 & dcpd & 1,3 & 13,1 & gravel & 52,0 & fly ash & 9,1 \\
\hline 14 & 28 & 24,5 & dcdp & 1,3 & 13,1 & gravel & 52,0 & $\mathrm{ph}$ & 9,1 \\
\hline 15 & 30 & 21,1 & dcpd & 1,1 & 20,0 & gravel & 57,8 & - & - \\
\hline \multicolumn{10}{|c|}{$\begin{array}{l}\text { Abbreviations: } \\
\text { dcpd-dicyclopentadiene } \\
\text { ph-phosphogypsum } \\
\text { str - styrene } \\
\text { tur - turpentine } \\
\text { fur - furfural }\end{array}$} \\
\hline
\end{tabular}




\subsection{Experimental tests}

The main aim of the batch composition was to produce durable sulfur concrete products, able to withstand environmental conditions, their exposure should be highly durable and immune to weather conditions. The following mechanical and durability tests were carried out:

- Water absorption [9]

- Bulk density [9]

- Compressive strength [10]

- Bending tensile strength [11]

- Determination of ultrasonic pulse velocity [12]

- Freeze-thaw resistance [9]

- Freeze-thaw resistance in salty environment - scaling [13]

- Abrasion resistance [13]

All of experimental tests were carried out according to the European or National Standards listed in references.

Additionally, after performing series of freeze - thaw cycles to sulfur concrete specimens, it was decided to test freeze - thaw resistance of sulfur polymer itself. Tests were conducted according to the Polish Standard PKN-CEN/TS 12390-9:2007 [14].

\section{Test results}

Cuboid polymer specimens of sulfur polymer $(40 \times 40 \times 160 \mathrm{~mm})$ were subjected to the freeze - thaw cycle test in a temperature ranged between $-20^{\circ} \mathrm{C}$ and $+20^{\circ} \mathrm{C}$ within one cycle. All specimens, irrespectively of the modifier, cracked in a short time after freeze - thaw cycles have begun (Fig.1). First cracks have appeared on a surface of polymer specimens within first 72 hours, full cracks (when a specimen breaks) were observed after 7 days from beginning of the tests.

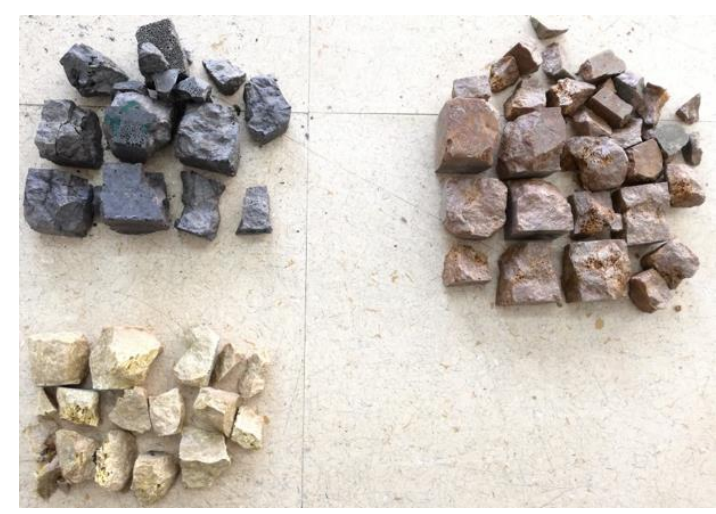

Fig. 1. Cuboid samples of sulfur polymers after 75 freeze - thaw cycles.

The polymeric binders were not affected by additives such as flying ash and phosphogypsum. Application of additives in dust form and aggregate of a good quality guarantees obtaining product of low water absorption and high compressive strength. Application of coarse aggregate with $2-8 \mathrm{~mm}$ graining in the mixture resulted with a significant improvement of strength parameters of sulfur concrete (Table 2, Fig. 2). 
Table 2. Mechanical parameters of selected sulfur concrete batches.

\begin{tabular}{|c|c|c|c|c|c|c|c|c|}
\hline \multirow{2}{*}{ No. } & \multirow{2}{*}{$\begin{array}{c}\text { Batch } \\
\text { No. }\end{array}$} & Density & $\begin{array}{c}\text { Water } \\
\text { absorption }\end{array}$ & \multicolumn{2}{|c|}{$\begin{array}{c}\text { Compressive } \\
\text { strength }[\mathrm{MPa}]\end{array}$} & \multicolumn{2}{|c|}{$\begin{array}{c}\text { Bending strength } \\
{[\mathrm{MPa}]}\end{array}$} & $\begin{array}{c}\text { Ultrasonic } \\
\text { wave } \\
\text { velocity } \\
{[\mathrm{km} / \mathrm{s}]}\end{array}$ \\
\cline { 3 - 8 } & & {$\left[\mathrm{kg} / \mathrm{m}^{3}\right]$} & {$[\%]$} & Early & Late & Early & Late & - \\
\hline 1 & 3 & 2285 & - & 41,0 & 41,0 & 4,3 & - & - \\
\hline 2 & 6 & 2160 & 0,23 & 14,5 & 18,0 & 4,2 & 4,2 & 3,44 \\
\hline 3 & 8 & 2053 & 0,37 & 12,1 & 14,2 & 4,1 & 4,1 & 3,15 \\
\hline 4 & 10 & 2029 & 0,36 & 11,2 & 14,1 & 3,4 & 3,8 & 3,23 \\
\hline 5 & 12 & 2351 & 0,35 & 57,3 & 56,1 & 8,7 & 7,7 & 3,91 \\
\hline 6 & 15 & 2296 & 0,31 & 65,6 & 53,4 & 5,2 & - & 3,82 \\
\hline 7 & 16 & 2387 & 0,47 & 57,0 & 51,7 & 7,3 & - & 4,15 \\
\hline 8 & 20 & 2235 & 0,07 & 50,6 & 68,7 & 13,3 & 10,4 & 4,07 \\
\hline 9 & 22 & 2300 & 0,10 & 39,7 & 45,8 & 7,4 & 2,3 & 3,97 \\
\hline 10 & 24 & 2241 & 0,06 & 38,4 & 41,9 & 4,9 & 5,3 & 3,94 \\
\hline 11 & 25 & 2256 & 0,04 & 49,6 & 50,5 & 4,5 & 3,7 & 3,79 \\
\hline 12 & 26 & 2420 & 0,25 & 54,5 & 54,6 & 5,5 & 5,8 & 3,89 \\
\hline 13 & 27 & 2341 & 0,04 & 58,7 & 58,2 & 10,1 & 10,0 & 3,82 \\
\hline 14 & 28 & 2390 & 0,04 & 61,8 & 51,3 & 8,0 & 5,7 & 3,91 \\
\hline 15 & 30 & 2300 & 0,13 & 55,4 & 44,9 & 7,0 & 5,5 & 3,76 \\
\hline
\end{tabular}

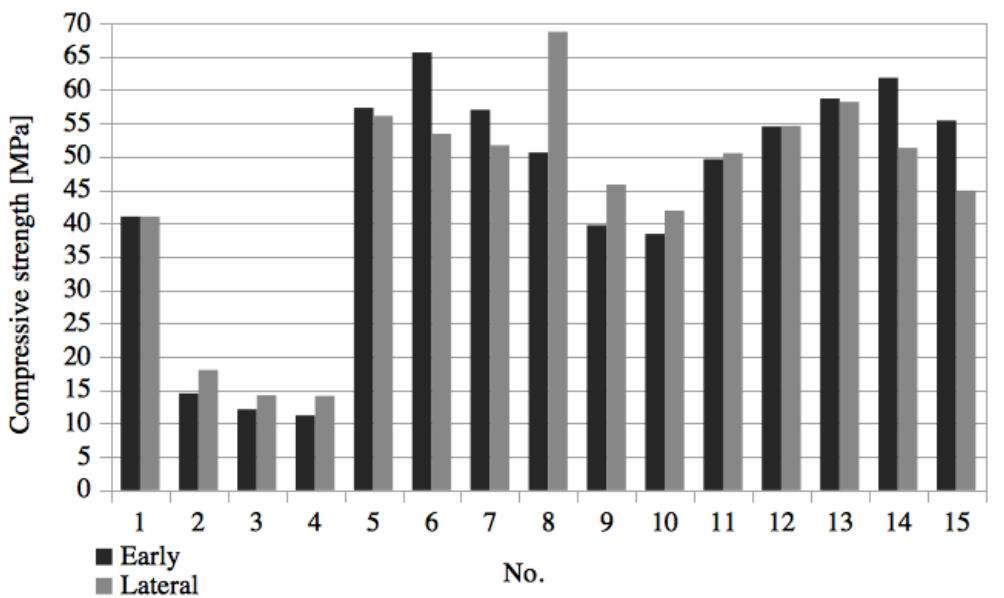

Fig. 2. Comparison of early and late strength of sulfur concrete samples.

Modification of sulfur polymer with styrene (STR) significantly decreased strength of the sulfurous mortar from 41,0 MPa to approximately 14,5 MPa. Natural aggregate (gravel, granite, dolomite) did not influence the compound strength. The curing time of samples did not affect the compressive or bending tensile strength. Early strength (1-4 days of age) and late strength after 28 days were similar (Fig. 2). The differences between the investigated parameters were caused by heterogeneity of the samples. The main reason of the results dispersion was varied conditions of samples casting. The time of casting is strictly limited, so the temperature changes significantly affected the final strength of sulfur concrete specimens. Additionally, differences in bending tensile strength observed on specimens tested in early and late stage of incubation might be connected with excessive maximum aggregate dimension contained in sulfur concrete $(8 \mathrm{~mm})$ for that kind of form $(40 \times 40 \times 160$ $\mathrm{mm}$ ), which is designed to test mortar parameters (maximum aggregate dimension of $4 \mathrm{~mm})$. 
The freeze-thaw resistance of sulfur concrete was conducted using volumetric and surface method. In the first one the strength loss limit is $20 \%$ of reference specimen strength and cracks on the surface of samples subjected to a specific number of freezingthawing cycles are not allowed. According to the Polish standard [14], concrete members used in the road infrastructure require the freeze-thaw resistance of F150, which corresponds to 150 freeze-thaw cycles. Several test specimens did not meet those requirements (Table 3 ).

Table 3. Durability test results of selected sulfur concrete batches.

\begin{tabular}{|c|c|c|c|c|c|}
\hline \multirow{2}{*}{ No. } & \multirow{3}{*}{$\begin{array}{c}\text { Batch } \\
\text { No. }\end{array}$} & \multicolumn{5}{|c|}{ Freeze-thaw resistance, samples compressive strength } \\
& & Reference & Tested & $\begin{array}{c}\text { Strength } \\
\text { loose }\end{array}$ & $\begin{array}{c}\text { Number of } \\
\text { cycles }\end{array}$ \\
\cline { 3 - 6 } & & - & - & - & - \\
\hline 1 & 3 & 16,6 & 12,0 & $28 \%$ & 200 \\
\hline 2 & 6 & 11,4 & 10,2 & $11 \%$ & 200 \\
\hline 3 & 8 & 9,1 & $27 \%$ & 200 \\
\hline 4 & 10 & 12,5 & 26,2 & $58 \%$ & 200 \\
\hline 5 & 12 & 61,9 & 36,3 & $35 \%$ & 200 \\
\hline 6 & 15 & 56,1 & 31,2 & $13 \%$ & 200 \\
\hline 7 & 16 & 35,8 & 46,8 & $29 \%$ & 100 \\
\hline 8 & 20 & 65,5 & 14,7 & $69 \%$ & 200 \\
\hline 9 & 22 & 46,9 & 29,3 & $31 \%$ & 200 \\
\hline 10 & 24 & 42,7 & 7,7 & $85 \%$ & 100 \\
\hline 11 & 25 & 50,4 & 7,7 & $85 \%$ & 150 \\
\hline 12 & 26 & 54,2 & 8,1 & $43 \%$ & 150 \\
\hline 13 & 27 & 55,4 & 31,5 & $27 \%$ & 150 \\
\hline 14 & 28 & 58,1 & 42,6 & $26 \%$ & 150 \\
\hline 15 & 30 & 59,1 & 43,6 & $26 \%$ & \\
\hline & & & & & \\
\hline
\end{tabular}

At the same time, frost resistance evaluated with the second method, by measuring the surface exfoliation of samples in water solution of de-icing salt $(\mathrm{NaCl})$, proved sulfur concrete very resistant (Table 4). The summary amount of the exfoliated material after 28 freeze-thaw cycles expressed in $\mathrm{kg} / \mathrm{m}^{2}$ was exiguous, and after 56 cycles did not exceed 0,3 $\mathrm{kg} / \mathrm{m}^{2}$.

The obtained abrasion test results affirmed that selected compositions of sulfur concrete are highly resistant to abrasion. The tested samples qualifies for the highest, $4^{\text {th }}$ class of abrasion resistance according to [13] (Table 5).

Table 4. Durability tests results - freeze-thaw resistance in 3\% salt solution (scaling).

\begin{tabular}{|c|c|c|c|c|}
\hline $\begin{array}{c}\text { Specimen } \\
\text { No. }\end{array}$ & $\begin{array}{c}\text { Mass of scaled } \\
\text { material after 28 } \\
\text { cycles (g) }\end{array}$ & $\begin{array}{c}\text { Mass of scaled } \\
\text { material after 56 } \\
\text { cycles (g) }\end{array}$ & $\begin{array}{c}\text { Mass of scaled } \\
\text { material after 28 } \\
\text { cycles }\left(\mathrm{kg} / \mathrm{m}^{2}\right)\end{array}$ & $\begin{array}{c}\text { Mass of scaled } \\
\text { material after 56 } \\
\text { cycles }\left(\mathrm{kg} / \mathrm{m}^{2}\right)\end{array}$ \\
\hline 1A & 1,50 & 2,51 & 0,16 & 0,26 \\
\hline 2A & 1,05 & 1,78 & 0,11 & 0,19 \\
\hline 3A & 0,21 & 0,64 & 0,02 & 0,07 \\
\hline 4A & 0,24 & 1,36 & 0,03 & 0,14 \\
\hline 5B & 0,03 & 0,11 & 0,00 & 0,01 \\
\hline 6B & 0,07 & 0,36 & 0,01 & 0,04 \\
\hline 7B & 0,01 & 0,10 & 0,00 & 0,01 \\
\hline 8B & 0,01 & 0,13 & 0,00 & 0,01 \\
\hline
\end{tabular}


Table 5. Durability test results of selected sulfur concrete batches.

\begin{tabular}{|c|c|c|c|}
\hline \multirow{2}{*}{$\begin{array}{c}\text { Specimen } \\
\text { No. }\end{array}$} & mean value & $\begin{array}{c}\text { width of groove }(\mathrm{mm}) \\
\text { results in correlation to } \\
\text { calibration sample }\end{array}$ & \multirow{2}{*}{$\begin{array}{c}\text { Class } 4 \\
\leq 20 \mathrm{~mm}\end{array}$} \\
\cline { 2 - 3 } & 15,1 & 20,0 & \\
\hline 2 & 14,4 & 19,0 & \\
\hline 3 & 15,0 & 19,5 & \\
\hline 4 & \multicolumn{2}{|c}{} \\
\hline
\end{tabular}

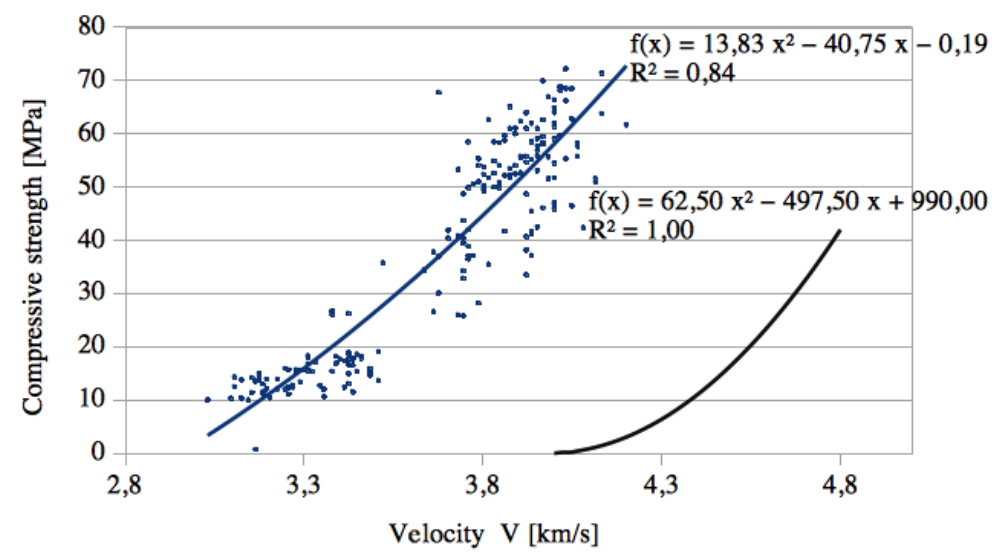

Fig. 3. Correlation curve of Compressive Strength - Velocity for sulfur concrete in comparison to standard curve for cement concrete according to PN-EN 13791.

In order to determine the compressive strength of sulfur concrete an ultrasonic pulse velocity method was used as well. The speed of wave for particular batches were repeatable and fall into between 24,1 and $31,0 \mu \mathrm{s}$, with an average speed value of $26,6 \mu \mathrm{s}$, which corresponded to a wave velocity of $3,76 \mathrm{~km} / \mathrm{s}$. The correlation between the velocity of an ultrasonic pulse in concrete and its compressive strength was estimated basing on the hypothetical curves or a reference tests. Acoustic parameters significantly depend on the tested material. For a typical, well condensed cement concrete with a density between 1800 and $2500 \mathrm{~kg} / \mathrm{m}^{3}$, the velocity varies between 3,0 to $4,8 \mathrm{~km} / \mathrm{s}$. The correlation between compressive strength and wave velocity for sulfur concrete in reference to the normalized curve for cement concrete is presented in Fig 3.

\section{Discussion}

The presented test results of sulfur concrete confirm low water absorption and high resistance to grating in dry conditions. The composite proved high freeze-thaw resistance in salty environment and can be recommended for production of small-sized prefabricated elements. Furthermore, the compressive and tensile strength of individual compositions allowed to design products of a high strength class. However, the sulfur concrete did not prove freeze-thaw resistance with cyclical freezing in the air and the thawing in a water. The probable reason of the vulnerability was the sulfur binder. Regarding this, the products made of the sulfur concrete cannot be exposed to severe conditions in Polish climate (XF class of environment exposition), as their durability does not meet the requirements of the Standards.

The research results clearly indicate that the material can be applied in the construction industry mostly for indoor and underwater or underground applications, below the freezing zone (for example underground cesspits). 
The additional restraint are sulfur's flammable properties, which are usually omitted, and relatively low melting temperature - around $130^{\circ} \mathrm{C}$.

Apart from further freeze-thaw resistance development, the evaluation of abrasion in water conditions is highly recommended due to possible application in underwater environment and all types of piping. Production of larger, reinforced sulfur concrete's members or even structures also requires further testing, but the starting point is the application of reinforcement that is immune to or properly protected from a corrosion. The composite bars seem to be a natural solution as the sulfur concrete occurs to be highly aggressive environment for conventional steel reinforcement.

In conclusion, despite the limitations of the obtained sulfur concrete composition, its potential applications are numerous and also economically justified.

The authors acknowledge financial support from the National Center for Research and Development and National Fund for Environmental Protection and Water Management for the applied research project GEKON No1/O5/213122/26/2015.

\section{References}

1. ACI Committee 548, ACI 548.2R-93 (Reapproved 1998) - Guide for Mixing and Placing Sulfur Concrete in Construction (1998)

2. Central Statistical Office - Statistical Information and Elaborations (2015)

3. M. Abdel-Mohsen, M. El Gama, Cement and Concrete Composites, 31, 186-194, (2009)

4. M.M. Vlahovic, Martinovic, Construction and Building Materials, 25, 3926-3934, (2011)

5. S. Myoungsu, K. Kyuhun, Construction and Building Materials, 69, 167-176 (2014)

6. M. M. Vlahovic, M. M. Savic, Materials and Design, 34, 346-354 (2011)

7. M. Abdel-Mohsen, D. Amr El, Journal of Environmental Geotechnics, 2(2), 95-103 (2014)

8. I. Błasiak, Ł. Łuszczyk, Chemik 41(9), 243 (1988)

9. PN-88 B-06250 - Ordinary Concrete

10. PN-EN 12390-3:2011 - Testing hardened concrete - Part 3: Compressive strength of test specimens

11. PN-EN 196-1:2016-07 - Methods of testing cement - Part 1: Determination of strength

12. PN-EN 12504-4:2005-09 Testing concrete. Determination of ultrasonic pulse velocity

13. PN-EN 1338:2005 - Concrete paving blocks - Requirements and test methods

14. PKN-CEN/TS 12390-9:2007 - Testing hardened concrete - Part 9: Freeze-thaw resistance - Scaling 